\title{
RULERS AGAINST WRITERS, WRITERS AGAINST RULERS: THE FAILED PROMISE OF THE PUBLIC SPHERE IN POSTCOLONIAL NIGERIAN FICTION
}

\author{
AYo KeHINDE* \\ University of Ibadan
}

\begin{abstract}
Various literary critics have dwelt on the nature, tenets and trends of commitment in Nigerian literature. However, there is paucity of studies on the imaginative narration of the impediments facing the actualization of the public sphere in postcolonial Nigeria. This paper examines the strategies and techniques of representing the failed promise of the public sphere in postcolonial Nigerian fiction, using the examples provided by Chinua Achebe's Anthills of the Savannah, Ben Okri's The Famished Road and Chimamanda Ngozi Adichie's Purple Hibiscus. The methodology involves a close reading of the selected texts, using Jurgen Habermas' Public Sphere as analytical concept. In the selected novels, Nigeria is depicted as a country where the rulers disallow the existence of the 'public sphere', which is supposed to provide a liminal space among the private realms of civil society and the family, as well as the sphere of public authority. This is disclosed in the refusal of the characters, who typify the rulers, to disregard status altogether.
\end{abstract}

Keywords: Public Sphere, Postcolonial Nigerian Fiction, Chinua Achebe, Ben Okri, Chimamanda Adichie, Jurgen Habermas.

* Correspondence should be sent to: Dr. Ayo Kehinde. Dept. of English. University of Ibadan. Nigeria. Email: ayobamikehinde2000@yahoo.com/ma.kehinde@mail.ui.edu.ng 


\title{
GOBERNANTES CONTRA ESCRITORES, ESCRITORES CONTRA GOBERNANTES: LA PROMESA FALLIDA DE LA ESFERA PÚBLICA EN LA FICCIÓN NIGERIANA POSCOLONIAL
}

\begin{abstract}
RESUMEN. Diversos críticos literarios se han detenido a analizar la naturaleza, los principios y modos de compromiso en la literatura de Nigeria. Sin embargo, hay una carencia de estudios sobre la narración imaginativa de los impedimentos a los que se enfrenta la actualización de la esfera pública en la Nigeria poscolonial. Este ensayo examina las estrategias y técnicas en la representación de la promesa fallida de la esfera pública en la ficción poscolonial nigeriana, utilizando los ejemplos que proporcionan Chinua Achebe en Anthills of the Savannah, Ben Okri en The Famished Road y Chimamanda Ngozi Adichie en Purple Hibiscus. La metodología implica una lectura detallada de los textos seleccionados, usando el término "esfera pública" de Jurgen Habermas como marco conceptual. En las novelas seleccionadas, Nigeria se representa como un país donde los gobernantes desestiman la existencia de la "esfera pública", que se supone que proporciona un espacio liminal entre los ámbitos privados de la sociedad civil y la familia, así como en la esfera de la autoridad pública. Esto se revela en el rechazo de los personajes que tipifican a los gobernantes a ignorar un status todos juntos.
\end{abstract}

Palabras clave: esfera pública, ficción nigeriana poscolonial, Chinua Achebe, Ben Okri, Chimamanda Adichie, Jurgen Habermas

Received 15 June 2009

Revised version accepted 30 July 2010

\section{INTRODUCTION}

Habermas' perspective on the Public Sphere is unarguably an influential variety of Marxism. His theory has, however, grown and become more diverse, "as he has addressed, and incorporated, the ideas of a wide number of sociological theorists, most recently and most notably those of George Herbert Mead, Talcott Parsons, Alfred Schutz, and Emile Durkheim" (Ritzer 2000: 548). Habermas's major focus is on communicative action; he believes that free and open communication is a pertinent ingredient for sustainable political development in any society. To him, "the construction of an unlimited and undistorted discourse can serve at most as a foil for setting off more glaringly the rather ambiguous developmental tendencies in modern society" (Habermas 1987: 107). Habermas's focal interest is the way in which the public sphere is perverted in contemporary societies.

The 'Public Sphere', viewed from the perspective of literature, is a polysemic concept, designating, as it does, a form of art, an ideological thrust, a purpose and 
a literary tone. For many years, much thought on this topic has been influenced by Jurgen Habermas, who proposes that, in eighteenth-century England, middle-class citizens began to see themselves as effective members of a rational public. Communicating ever more volubly in café society, literary clubs and the press, more and more British subjects could see it as their proper role to debate and pass judgements on matters they deemed important to the collective life of the nation. This set of communicative institutions and behaviours Habermas designates 'the bourgeois public sphere' (Habermas 1991: 12). Fraser (1992: 110) argues that the public sphere is a "conceptual resource designating a theatre in modern societies in which political participation is enacted through the medium of talk. It is the space in which citizens deliberate about their common affairs, and hence an institutionalized arena of discursive interaction". Thus, the public sphere is an ideal of unrestricted rational discussion of public matters, a space where interlocutors set aside characteristics, such as difference in birth and fortune, and speak to one another as if they were social and economic peers. However, gender, sex, race, ethnicity, social class, and many other factors always affect the operation of the public sphere. Therefore, this mode of communicative rationality was displaced, in subsequent centuries, by the logic of consumer capitalism (Habermas' real target). Whether anyone at the time really imagined himself or herself taking part in the pure exchange of ideas is debatable.

The primary tenet of the ideal public sphere, in Habermas' conception, is similar to the experience of the Nigerian masses who were always involved, at least indirectly, during the pre-colonial era, in the gathering of public opinion on politics, commerce, entertainment, the arts, ecology and religion. For instance, among the Yoruba of southwestern Nigeria, in the past, the calabash would be opened for a bad king whose rule was threatening the life of the community. This is an aroko (sign communication), telling him to vacate the throne through an act of suicide. At Onitsha, in Anambra State of Nigeria, a king whose reign threatened the life of the community would be asked to vacate the throne and commit suicide by ritual death through the occupation of the throne by a royal masquerade. This signifies a condition of equality among speakers and listeners, not necessarily in wealth or social influence, but in the ability to speak and be heard. In the public sphere, people become important, because other people find their actions or attributes worth talking about. A public figure can become so only by the rational affirmation of many citizens speaking to one another. According to Glover (2004: 10), "to be public is to do something that the public will recognize and acclaim". This is also the case of fictional heroes in prose fiction whose virtues make them admirable.

However, Habermas himself points out, in a brief aside on Goethe's Wilhelm Meister's Apprenticeship (1991), that this idea of the public sphere does not always sit well with the people it supposedly benefits. Rather, most of them go for 
Monarch's Publicness whereby they appear as superior beings and as allegorical figures representing something greater than their individual persons. They scarcely try to enter discussions or appeal to the judgement of the citizens. In fact, they reject the contest of ideas, thereby behaving like anti-heroes or antagonists in prose fiction. According to Habermas, the life-world and communicative action are 'complementary' concepts. Specifically, communicative action can be seen as occurring within the life-world, which is "the transcendental site where speaker and hearer meet, where they reciprocally raise claims that their utterances fit the world [...] and where they can criticise and confirm those validity claims, settle their disagreements, and arrive at agreements" (Habermas 1987: 126). However, the complementary relationship between the life world and communicative action is subverted in many neo-colonial African nations, including Nigeria, which is the main focus of this paper.

Against this background, this paper examines the troubles that Nigerian writers face in carrying out the task of exposing their rulers' efforts to alienate the governed from the public sphere. It also investigates and critiques three fictional case studies of the ways in which neo-colonial Nigerian rulers exclude some citizens from the utopian space of the public sphere. In the main, there is an attempt to explore the socio-economic and political dimensions of Habermas' concept, the public sphere, as represented in selected Nigerian novels. It is argued that Achebe's Anthills of the Savannah, Ben Okri's The Famished Road and Chimamanda Adichie's Purple Hibiscus yield singular insight and provocation to a theoretical understanding of the concept of the public sphere. It is also argued that Nigerian postcolonial fiction is an indispensable medium for teasing out and exploring the antithetical meanings embedded within the notion of the public sphere. By revealing the unfairness of the contemporary regime of the public sphere in the nation, postcolonial Nigerian fiction paradoxically suggests a location for a re-conceptualization of a newly invigorated, capacious and robust vision of social justice in the nation.

\section{THE SWORD AND THE PEN: AN ENDURING DISSONANT RELATIONSHIP}

Knowledge is developing, and the divisions that existed among different disciplines are being erased. This informs the synergy between literature and fields of social sciences and Human Communication. Thus, the rapprochement between African fiction and Jurgen Habermas' theory of the public sphere is not an anathema. Most African writers are useful as watchdogs in their societies, as they help protect the public from those who do harm - from high government officials to petty criminals. They help to shape public thought, spark debates and fight for societal good and against societal ills. They embolden the masses and give them 
hope when it seems there is none. Writers may be too critical and too adversarial or become like mere lapdogs, too timid to take on the sometimes dangerous, often tedious and costly task. Over the years, politics and socio-historical realities have exerted a pull on Nigerian writers. However, writers' endeavours to expose and critique the misdeeds of rulers have always been challenged.

The ancient beliefs that the poet (writer) has magical powers still survive in certain distorted ways today. In early European culture, the writer was associated with awful audacity. He had the ability to encroach on divine prerogative, akin to the Yoruba belief that the writer is a sacred cow. In traditional Yoruba society, the writer was sacred, even for a king. Therefore, he - simultaneously - was an object of peoples' admiration, target of their ambivalence, dogged, and heroically prepared to die in defence of the ancient right of poets. He stood in a very special relation to his society by enhancing its well-being, defending it from its enemies, and mediating between the governed and the rulers. However, all the writer's virtues, rights and obligations came with their complementary danger, both personal and social. He was an object of hatred and fear, honoured and loved for his patriotic roles. He was hated and feared because of his power to expose ills. Such was and is the ambivalent attitude of society toward its writers. The ancient law, most especially The Roman Twelve Tables, threatened with death anyone who would "chant an evil charm" (Elliott 1972: 262). Plato's laws also recommended extremely severe penalties against similar activities (Elliott 1972: 260). Old Irish law undertook, zealously, to regulate the activities of writers, making provision for the reward of 'good' writing (directed toward socially sanctioned end) but laying down heavy penalties for 'bad' writing, that which wantonly injured (Elliott 1972: 260). Writers were then banned on libels, skated on the thin edge of censorship and legal retribution.

Creative writers face comparable problems today. Even in democratic countries, like Nigeria, the writer attacks individuals only at the risk of grave financial loss to himself and his publisher; he also risked death during the era of military dictatorship that ended in 1999. In fact, there are lots of demonstrable effects of socio-political and economic pressures on Nigerian writers in forms of restrictions and repressions. In Nigeria, like in many other countries of the world, freedom of expression and the press/writer is the exception rather than the rule. Some writers in the country have been subjected to imprisonment, and some have been gruesomely murdered. There seems to be a cold war between the sword (the ruler) and the pen (the writer) in Nigeria. Freedom House rates Nigeria news media as "partly free", with 53 points on a scale of zero to hundred (www.freedomhouse.org//accessed 23 July, 2008). Behind this rating is Nigeria's constitution which guarantees freedom 
of expression and of the press. However, the security apparatuses of the country, most especially the police and other armed forces, often act arbitrarily and use extra-legal measures to suppress political criticism and expression in the media and creative writings. Libel remains a criminal offence in Nigeria, and the burden of proof in such cases rests with the defendant. Nigeria's State Security Service is known to use arbitrary detention and extra-judicial measures in attempts to suppress freedom of speech and muffle political activism and criticism.

Do writers attack institutions or perversions of institutions? To Frye (1945), a writer attacks primarily neither the man nor the institution; he only attacks an evil man who is given gigantic stature and protected by the prestige of the institution. In Frye's words, "the cowl might make the monk if it were not for the satirist" (1945: 80). However, rulers frequently react violently against writers' attacks, which they conceive as embarrassing and insurgence. What primarily stands as a personal attack often ends by calling the whole position which the individual occupies into question. Therefore, the ruler will keep on suspecting the writer, and the relationship of a writer to society will necessarily remain problematic. A very recent example of the dissonant relationship between rulers and writers in Nigeria was the conflict between the writers in Kano State and the Censors Board that was constituted and inaugurated by the government of the state. In his defence of the government's attempt to censor all publications in the state, Abubakar Rabo, the Director-General affirms that:

Knowing how important reading is to the development of the mind, it is very essential that we safeguard what the public is reading, especially our youths. There are some literatures that are obscene going around, such are the types we are trying to kick against (The Nation, August 6, 2008: 26).

However, some Nigerian writers see the Censors Board as outrageous and anachronistic. For instance, Denja Abdullahi, the National Secretary of the Association of Nigerian Authors (A.N.A) in a quick reaction to the setting up of the board, opines that:

The action is condemnable. It is like taking us back to the Stone Age. Banning of literature in a society sets it back to the time of the Stone Age. It is not good for the country and the society at large. There is no need for that. Presently, there is no place in the world where such is done (The Nation, August 6, 2008: 27).

Osundare frankly lampoons the Board:

Censors board? What does Censors board have to do with writing? It is backward and extensively diversionary. This is grotesquery. I thought we had left this behind hundreds of years ago. At a time when the whole world is moving forward, Nigeria appears to be backward, and with this development, then, it shows that we are 
actually retrogressing very fast. This takes us back to 1744 when John Milton the great English poet wrote Areopagitica. He did it in respect of free speech and unhampered expression (The Nation Newspaper, August 6, 2008: 27).

Thus, it is an open secret that there is an uneasy relationship between the rulers and the writers in Nigeria. Governments have always imposed varying levels of censorship on the writers. Even, whether censored or not, their works are, at times, subjected to intense scrutiny. At one extreme, Nigerian writers, including the Nobel Laureate Wole Soyinka, Ken Saro-Wiwa, Festus Iyayi and Ogaga Ifowodo, have been called propagandists, labelled unpatriotic, even treasonous. However, freedom of writers and the press is a cornerstone of democracy. People have a need to know, and writers have a right to tell. Nigeria is experiencing unusual social and political excesses, and there is an alarming climate of political, social and economic tensions in the country. A writer's responsibility in exposing and condemning these excesses includes the duty to be fair and objective.

\section{FICTIONAL CASE STUDIES OF THE FAILED PROMISE OF THE PUBLIC SPHERE}

Nigerian writers are still vibrant and especially vocal against unpopular state policies despite the upheaval and violence against them. They serve as a source of inspiration and consolation through their works, during the reigns of despots who enact poison-tipped policies, ruling the nation with rod and scorpion. During the period of dictatorship, the country does not progress as it is supposed to; only official corruption, official killing, do-or-die politics and the like thrive unabated. Most Nigerian writers rise to the occasion and challenge governments' excesses that are detrimental to the well-being of the nation and her citizens. Actually, what Nigerian writers are doing to sustain the evolving democracy is indeterminate. One wonders what the nation would have become in the hands of the neo-colonial rulers of the country if the Nigerian writers have hung up their pens. Integral to this conviction is Williams's contention that:

African writers have resisted oppression and injustice on the continent with great force and courage. Literature is fundamentally incompatible with tyranny. In its purest state, literature is subversive of authority and authoritarian rulers. Its joyous and spontaneous celebration of life, its near anarchic contempt for regulation and regimentation makes it the most natural enemy of dictatorship. While the dictator seeks a total domination of men and society, literature often seeks their total liberation (1996: 350).

Therefore, the indispensable role of literature for effectuating communal restructure in Nigeria is more than ever before required. It is no longer a question of how the British colonialists 'ruined' the country, but of how Nigerian leaders 
have aborted the great hopes and expectations of independence. Therefore, in support of Osundare's (2007) assertion, socio-political commitment is not an aside, a parenthesis or a footnote in the creative consciousness of postcolonial Nigerian writers. Most of them write not only to entertain and please, but to change their society in the process.

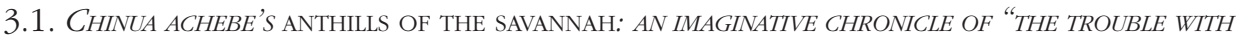 NIGERIA'S" PUBLIC SPHERE}

In his essays and interviews, Achebe maintains that literature is a communal celebration in Africa. Therefore, the African writer has no choice but to be committed, for there is no room for art for art's sake; rather, in Africa, there is always art for life's sake (Kehinde 2005: 266). In his texts, Achebe traces the trouble with Nigeria to the doorstep of tribalism, absence of patriotism, social injustice, indiscipline, corruption, and the like. These vices, Achebe (1984: 3) believes, originate at the top of the political order and work their way down.

Concern with the Public Sphere and the necessary conditions for a genuine democracy, which is the critical theme of Haberma's concept of the public sphere, is the foundational preoccupation of Achebe in Anthills of the Savannah. Following the example offered by JanMohamed in his analysis of Achebe's writing through Georg Lukács's theory of realism, the main characters in Anthills of the Savannah are held in this paper to be profoundly alienated or about to be alienated from their society. Achebe employs three main characters (Ikem Osodi, the Editor of the National Gazette; Beatrice Okoh, Senior Assistant Secretary, Ministry of Finance; and Chris Oriko, the Commissioner for Information) who narrate the story in turns. With this unique narrative point of view, the reader is able to learn more about His Excellency (Sam) and understand the problem of the failed promise of the public sphere in Nigeria from a multi-dimensional perspective. Sam is depicted as a ruler who does not tolerate the voice of the citizens of his country. This is antithetical to the tenets of the public sphere.

Anthills of the Savannah is Achebe's most sustained treatment of political issues in post-independence Nigeria. The president of a fictional African state, Kangan (unmistakably Nigeria) is intoxicated with power. In The Trouble with Nigeria, Achebe (1984: 1) affirms that the 'trouble' with the country is "simply and squarely a failure of leadership"; Anthills of the Savannah is the fictional exposition of this source of failure. In the text, there is a transition from love and friendship to disillusionment and violence. The President, in his anti-public-sphere temper, does not tolerate dialogue, constructive criticism, egalitarianism and communication. He does not allow the public sphere to exist in his domain, because it is seen as an anathema. 
In the world of the novel, the public sphere is not allowed to materialize. The expected avenue "made up of private people gathered together as a public and articulating the needs of society with the state" (Habermas 1991: 176) is not allowed to function in the cosmos of Achebe's Anthills of the Savannah. Rather, flattery comes to assume the place of real debate, and the moral force of governing is displaced by an internal power. For instance, the narrator believes that, in order not to irk the president, it is good to "keep your mouth shut" (2). The Head of State even says authoritatively: "You know I've never relied on you fellows for information on anything or anybody" (15). He informs the Commissioner for Justice and Attorney-General: "You may be the Attorney, but don't forget I am the General" (24). Surprisingly, the Attorney-General also concurs by saying: "[ ... ] we have no problem worshipping a man like you" (24). This reverence is due to His Excellency's socio-economic background. The Attorney-General attended a "bush grammar school", unlike His Excellency who was born with a silver spoon in his mouth and attended an elite school. In fact, within two years of holding the reign of governance, Sam has become a totalitarian dictator. The government is absolute in power; it "holds the yam and holds the knife" (33). Beatrice Okoh, an official in the Ministry of Finance and girl friend of Chris, testifies to the sudden negative metamorphosis of the president:

In the early days of his coming to power I had gone fairly often to the Palace with Chris and sometimes Chris and Ikem. But then things had changed quite dramatically after about a year and now apart from viewing him virtually every night on television news I had not actually set eyes on him nor had any kind of direct contact for well over a year (71).

The President recoils up the hill, communes with his cronies and forgets the very people who legitimize his authority. As a dictator, he banishes the public sphere from his governance. This attests to the fact that many postcolonial African leaders tend to forget that, in Africa, every event or person is connected, interrelated and dependent in order to exist. The President of Kangan fails to observe this popular tenet; instead, he engages in massive corruption, subservience to foreign manipulation, second-class hand-me-down capitalism, damnable shooting of striking workers and demonstrating students, and destruction and thereafter banning of independent unions and cooperatives. There are lots of fugitives in the fictional nation of Kangan (Nigeria); for instance, Emmanuel Obete, a former President of the Students Union. These problems are attributed to the failure or neglect of the public sphere in the nation, that is: "the failure of our rulers to re-establish vital inner links with the poor and dispossessed of this country, with the bruised heart that throbs painfully at the core of the nation's being" (Anthills of the Savannah, 141). 
The leadership style of His Excellency, Sam, shows that the military operates on the basis that "might is right", and is usually tyrannical in approach. In fact, the ordeals of the people of Kangan reveal that military rulers are mostly dictators under whom the masses suffer untold economic and psychological hardship. And for the simple reason that man desires comfort, he rebels against oppressive tendencies in the rulers. Young (2004) makes a similar comment on this claim thus:

\begin{abstract}
Military intervention became the sole mechanism to displace incumbents, but the putschist in power normally formed a new single party to legitimize permanent status for his rule. Thus citizens became once again merely subjects, facing an exclusion from the public domain reminiscent of colonial times. One important difference: whereas the colonial state asked only obedience, the post-colonial polity demanded affection. Mere submission did not suffice; active participation in rituals, loyally (support marches, assemblies to applaud touring dignitaries, purchase of Party cards, display of the presidential portrait, participation in plebiscitary elections) were mandatory (25).
\end{abstract}

Because the people become terrified under dictatorship, just a few courageous members of the society take it upon themselves to bear the burden of all and sundry. These individuals become martyrs and heroes in the process. It is the attempt by a few courageous individuals to create an alternative voice through which the masses can be informed of developments in their society that gives rise to the resistance temper which runs through Achebe's Anthills of the Savannah.

According to Habermas (1991), an independent press assists tremendously in intensifying the public discussions that take place in the public sphere. However, in Anthills of the Savannah, it becomes rather difficult for the press to write and publish what is true. The attempt of the press to ignore the warning signal, the brutality that befalls the masses of the nation, would have served as a cruel reminder of an intolerant regime that permits and promotes falsehood above national ethics and moral ethos. Oppressive and repressive regimes antagonise freedom of speech to their personal advantages. Since words alone cannot sufficiently bring down a tyrant, there is, therefore, the need for collaboration between the press and members of the 'pro-democracy' and pressure groups to create a bigger platform with which the tyrant is confronted and hunted down eventually. Therefore, Sam's attitude to opposition, especially critical views by the press, makes Ikem and his collaborators (Beatrice, activists, labour leaders, and the like) utilize alternative means of resisting the draconian rule of military dictatorship.

To Ikem, journalism is not meant to make the environment cosy for leaders who are despotic. It is meant to prod them to act in the interest of the larger society and cause them sleepless nights (Ajibade 2003: 39). The press is one organised group that has helped to give bite to the cause of human struggle and resistance 
against oppression and oppressors in the nation of Kangan. This is a commendable action because, if the press abdicates this responsibility, there would be problems; the leaders would be operating without restraints. This is in consonance with Habermas' view that 'inasmuch as the mass media today strip away the literary husks from the kind of bourgeois self-interpretation and utilize them as marketable forms for the public services, provided in a culture of consumers, the original meaning is reversed" (1989: 171).

According to Ojinma (1991: 61), "such concepts, as moral principles, tolerance for opposition, and the use of power for the benefit of the people, do not have much meaning to the leaders" (61). Sam begins to demonstrate his despotism at a cabinet meeting when he obstinately refuses to visit the drought-stricken province of Abazon. He wants no opposition, and, at all cost, demands the submission of a dissident province to the central authority. He addresses and harasses his cabinet without caring whose ox is gored. His high-handedness is, thus, reflected in his abusive words to Chris, the Commissioner for Information: "I will not go to Abazon. Finish! Kabisa!" (1). This rejection of assembly and dialogue unveils the stark reality that military dictators habitually distance themselves from the people they rule. Sam orders Professor Okong, the Commissioner for Home Affairs, to meet the Abazon delegates and give them empty promises about the welfare of the dispossessed and forgotten inhabitants of the province. He urges the Commissioner to: "find some nice words to them. Tell them we are tied up ... with very important matters of the State...tell them they can rest assured that their complaints or rather problem ....will receive His Excellency's personal attention" (17). Therefore, Sam, in his anti-public-sphere posture, rejects the opportunity of generating opinions and attitudes which could have served to affirm or challenge, and, therefore, guide the affairs of the nation. Consequently, there is no ideal public sphere in Kangan, due to the anti-democratic temper of the Head of State, who, according to Rutherford (2000: 18), refuses the public opinions needed to "legitimate authority in any functioning democracy". Therefore, in Kangan, legitimate law and democratic rule are not compatible. This is because the latter does not "have an internal relation to the search for truth" (Habermas 1996: 475). To Habermas, "public discourse must mediate between reason and will, between the opinion-formation of all and the majoritarian will-formation of the representatives" (Popular Sovereignty 1996: 475).

Thus, abuse of human rights is an endemic problem engulfing the fictional State of Kangan. It is right, therefore, to support Ojinma's (1991: 86) assertion that "Achebe sees the soldiers as not being any better than the civilians they ousted [...] they have become worse, having perfected torture, intimidation and cold-blooded killing as weapons to cow the opponents of their policies". In his bid to undermine 
Press freedom, Sam charges Chris to check the Editorial 'excesses' of Ikem, the Editor of the state-owned newspaper, The Gazette, so that the naked truth of the president's dictatorship would remain covered. Cases of arbitrary arrest which are replete in Kangan also corroborate the satanic inclination of the military tyrants to unleash the reign of terror on dissidents, as demonstrations, whether peaceful or violent, become a taboo. Six Abazon leaders are brutally punished because of their alleged complicity in staging a protest against the military despots. The omniscient narrator explains: "Six leaders from Abazon who were involved in a recent illegal march on the Presidential Palace without police permit as required by decree had been arrested" (150).

The educated elite living in the capital city (Chris, Ikem and Beatrice) believe in the creation of a nation-state; they refuse to accept the distinction between State and nation, as practised by Sam, the Head of State and the people of Abazon. The elite, due to their respect for the public sphere, believe in identifying a State and a national atmosphere where the ruler must come from among the people of the nation, identify with them, and the people, in turn, would identify with the State. However, Sam's regime, because of its apathy towards the Habermasian public sphere, does not allow the masses to have a stake in the country. Even, there is isolation of the governing elite from the masses, symbolized by the air conditioner in the Council Chamber. This literally cuts off the noise of the people protesting outside, thereby depriving the elite of a vital source of socio-economic knowledge in the everyday experience of the people, which should have informed its political consciousness. Sam turns his cabinet to a group of timorous courtiers and hedonists, who only strive for personal survival and advancement. No critical debates essential for informed process of policy-making exist in the cabinet.

Ikem, a seasoned journalist, is expected to proclaim and protect the President's image by disseminating only what he tells him. On the contrary, Ikem holds tenaciously to the freedom of the press. Achebe seems to rely on the courageous and principled stance that some members of the elite take to envision a nation where the yearning of the masses for the public sphere is met. Ikem, for instance, attempts to provide genuine independent political opinions. However, he is soon labelled as subversive and, subsequently, murdered by a security police. He traces the trouble of the nation to "the failure of our rulers to establish vital links with the poor and disposed of his country, with the bruised heart that throbs painfully at the core of the nation's being" (141). Sam is killed in a coup, and his tragic flaw is his inability to embrace the establishment of a nation-state. He encourages the potentially disastrous discrepancy between the state and the nation. To Habermas, the existence of a distinct public sphere mainly rests upon access to full information being guaranteed to all citizens, not just only self-selecting and 
more or less privileged particular public as the case is in Sam's Kangan. Also, the key idea of attaining Truth through unrestricted public discussion among knowledgeable citizens is not allowed by the despot. Through the misrule of Sam, Achebe has, therefore, taken the wrapping off the military government and laid bare its perfidies.

Incompatibility of social classes leads to inevitability of conflicts and struggles. The society is completely in the grip of the 'petit bourgeoisie' and the intelligentsia. The oppressed and deprived people (the workers and peasants) are not given major roles to play in the society. According to Emmanuel Ngara (1990: 122), they are "either pushed to periphery or relegated to oblivion". There is a huge gap between the hybrid class of intellectuals and the class of oppressors. This rape of democracy, that is the failure of the public sphere, leads to crisis in the society that is depicted in the novel. There are agitations for free debates against the encroachment of totalitarian control of the military despot and his collaborators, popular protests and later a coup d'état. Since Sam refuses to carry out exchange of ideas with people in public arenas, that is, he refuses to dialogue with the Abazon delegates, Ikem persists in believing that he can, through his Editorials in The Gazette, make the President realize that despotism is an abomination in a democratic state. This is achieved through the efforts of Chris, Ikem and Beatrice to re-establish bonds with the people (shops saleswomen, taxi drivers, student activists, trade unionists, village elders, and the like). Through this effort, they are able to forge at least a brief period of national solidarity and truly representative political consciousness.

Commendably, the hybrid classes of intellectuals - Chris, Ikem and Beatrice as representatives - are dynamic characters who take on the responsibility of playing a redemptive role in the society. Kangan workers and peasants are depicted as a social class with enormous potential. This unity-in-diversity temper shakes the rule of His Excellency and frightens him. In his early study of students and politics, Habermas defended the principles of popular sovereignty, formal law, constitutionally guaranteed rights and civil liberties as part of the progressive heritage of bourgeois society. Similarly, the masses of Kangan prove that they are unwilling to remain oppressed, but would rather choose to fight consciously against the lies, corruption and despotism of the ruling class in order to protect their interests. However, their revolutionary candour is with limitations. They are not able to fight effectively as they lack the power to do so. This is captured in the allegory of the battle between the Tortoise and the Leopard. Therefore, although the masses (the students, the taxi drivers, the transport union members, and the like) attempt to fight for their rights, they do not have any idealistic hope of winning; they only fight symbolically to gain some psychological satisfaction. This is why they need the intellectual guidance 
and inspiration of the hybrid class. However, the hybrid class, in its attempts to play a redemptive role in the society, faces two hurdles. In the first instance, the members of the class need to abandon their social status as members of the ruling class. Secondly, they need to immerse themselves in the mass of ordinary people, that is, identify themselves with the people and become part of them. They should, therefore, cross two class borders.

The heroic deaths of Chris and Ikem appear to [or serve to] educate the masses of Kangan and enable them to become aware that reconciliation among various social classes is essential for the unity of the nation. Achebe's prescription for the failed promise of the public sphere in the country is reconciliation among the various social classes. They should re-adjust and improve human relationship for the sake of the stability of the nation. The rulers should also humble themselves in order to truly understand and care about the people in the downtrodden class. The governed also need to make compromises while fighting to survive. This is revealed, for instance, in the cross-class love between Ikem and Elewa, cross-class understanding between Beatrice and Agatha, and especially in the new born baby, Amaechiwa (May-the-path-never-end) in Igbo.

Therefore, Achebe seems to suggest a solution to the trouble with Nigeria. For him, the Platonic Philosopher King, who would lend substance to position of leadership and defeat the cynicism of the people that he describes in the text, is the ideal ruler for the nation. Therefore, in Anthills of the Savannah, Achebe, more than ever before, admits the possibility of democracy in Nigeria. He imagines the feasibility or even the necessity of political agency originating from the masses rather than from the newly enlightened elite. This is very similar to Habermas' conceptual clarification of the public sphere in Student und Politik (1961) where he calls for democratisation and political participation.

\subsection{Ben Okri's The famished Road: A Magical Refraction of the Failed Promise of the PubliC SPHERE IN NIGERIA}

Radical democracy, which is envisioned in Okri's The Famished Road, is an overlooked subtext of many of Habermas' works on the public sphere. Although the text offers an insight into a pre-independence epoch, it is highly reflective of a post-independence African era, a revelation of the unsavoury intricacies that permeate the socio-political terrain of a developing country as a result of skewed human relationship and the failed promise of the public sphere. The Abiku myth is used as a political metaphor. The exploits and ordeals of the spirit-child, his vacillation between two worlds (terrestrial and extra-terrestrial) unfold in the 
socio-political, cultural and moral fabrics of the society. The episodic plot of the novel involves a quest motif, involving three characters (Azaro, Black Tyger/Dad and Jeremiah, the photographer). One of them (Azaro) is recognized at the apex of the identity-search ladder; the other two are significantly subsumed in the first, but their search is single-mindedly political. The pursuit of a humane and just society in the physical realm is uppermost in their consciousness. Azaro's attempt to navigate life towards self-discovery, as encompassed by the road myth, seems to be rough, tortuous and sinuous:

In the beginning, there was a river. The river became a road, and the road branched out to the whole world. And because the road was once a river, it was always hungry (1).

The road became my torment, my aimless pilgrimage, and I found myself walking to discover where all the roads lead to, where they end (114).

The major theme of Habermas' The Structural Transformation of the Public Sphere is that big economic and governmental organisations have taken over the public sphere, while citizens have become primarily consumers of goods, services and political administration. This is reflected in Okri's novel. For instance, through the exploits of Azaro, the reader is able to understand the rigour of existence: "the unfulfilled longings, the enshrined injustices of the world, the labyrinths of love, the ignorance of parents, the fact of dying" (3). The socio-political system is turned into a festering sore. The wide gulf between the rich and the poor is revealed in some people living in clover, while others are condemned to the impecuniousness of the slums, religious perversity, political insincerity on the part of both the Party of the Rich and that of the Poor, and other eccentricities. These impediments discourage Azaro from defining himself permanently within the corporeal reality. In the milieu imaginatively portrayed in this novel, revolutionary nationalist hopes have given way to the disappointments and disillusionment of the corrupt post-independence state that Fanon simultaneously describes and prophesies in The Wretched of the Earth. The succession of one corrupt regime by another (like the 'coming and going' of the 'Abiku' child) has been a persistent pattern that has defined the politics of almost the entire continent, and one which shows little sign of changing and abating.

Dad (Black Tyger), as a result of his abject poverty and unemployment, resolves to become a boxer to earn a living. His status as a boxer and non-conformist pits him against the Party of the Rich, the governing authorities, his landlord, and at times, Madame Koto - the last two being members of the Party of the Rich. Because of Dad's unyielding opposition to the Party, his landlord jerks up his rent, which he bemoans in statements tinged with socio-political rage: "where am I going to find 
that kind of money every month, eh? That's how they make you commit murder. Do you see how they force a man to become an armed robber" (237). He rebuffs his landlord's attempt to coerce him to vote for the Party of the Rich during an election: "what right has the landlord to bully us, to tell us who to vote for, eh? Is he God? Even God can't tell us who to vote for. Don't be afraid. We may be poor, but we are no slaves" (203). Thus, as suggested in Habermas' public sphere, Okri, in The Famished Road, prioritises democratisation; there is an emphasis on political participation as the core of a democratic society and as an element in individual self-development.

In essence, in the society portrayed in The Famished Road, politicians are presented as embodiments of greed and corruption. They are antithetical to the ideal envisioned in Habermas' public sphere. Okri is equally concerned with the indifference which most of the exploited members of the society show toward their conditions. The interrelationship and interdependence required of them to change the status quo is, however, lacking. In spite of the fact that Okri paints a bleak social and political picture of this period of Nigeria's history, he leaves everyone in doubt as to the solution to the problems he has portrayed. This confirms Cooper's (1998) assertion that Okri's novel is elusive "with regard to the possibility of change" (89). Okri's ability to create the impossibility of a stable and acceptable public sphere among the people situates the text within a particular historical period, and this removes it from being a mere magical realist novel and qualifies it as a social realistic text. It is when we consider these dissonant and discriminatory human interactions in the novel that the full impact of the social and political decadence strikes us fully. The actions and dealings of the characters reveal the reality of their socio-political world, and by implication, their economic situation.

The society depicted in the novel is polarized into the poor, represented by Dad's household, the rich, represented by Dad's landlord and Madame Koto. Okri shows that this society, like most stratified societies, is characterized by the exploitation of the poor by the rich. Dad and his neighbours are subjected to constant exploitation by the landlord. Even though the roof is leaking, the landlord continues to increase the rent and often threatens them with thugs. Only Dad is aware of their conditions and sometimes challenges him, while others seem to be less concerned. There are no serious and purposeful social interactions geared towards catalyzing a change among the deprived masses. Dad seems to be the only man of conscience struggling to change the society for good. His metamorphosis into a boxer is to improve the society, because his family have to cut down the food in order to afford the rent. Whereas their conditions worsen, those of Madame Koto and the landlord improve. Madame Koto transforms from the kind of woman who helps her needy neighbours. Her metamorphosis is so absolute that Azaro says: "she changed completely from the person I used to know, her big frame which seemed to me full of warmth now seemed full of 
wickedness. I didn't know why she had changed" (251). Madame Koto becomes a stranger to the ghetto dwellers when she comes in contact with the politicians. Through this negative metamorphosis, Okri conjures, in detail, the abuse of power and national resources by Nigeria's ruling class.

Dad, in his uncontrolled outburst declares: "some people have too much, and their dogs eat better food, while others suffer and keep quiet until the day they die" (380). His efforts to earn a livelihood afford him an insight into the realities of his society. He awakens to the realities that he, along with other members of his social class, has been condemned to lead a life of hardship and abject poverty from which it is impossible to escape. This situation is even worse on the political front. Political affiliation is well polarized along two lines (The Party of the Rich and The Party of the Poor). Okri has used this polarization to show the difference between the lifestyles of members of the Party of the Rich and their supporters and those of The Party of the Poor. For members of the former, wealth and power have become the principal pursuit, and the unavoidable consequence is a total disregard of any moral or social consideration in the drive to satisfy individual desires. This recalls Liman's (1999) comment that The Famished Road is "a way of depicting the life of the poor in Nigeria who are caught between the urge to live a better life and the difficulties of a system built on injustice and exploitation of man by man" (70).

For Okri, Nigeria is - metaphorically - an Abiku child who comes and goes at will. For instance, Dad has a similar notion, as he observes and avers that: "ours too was an abiku nation, a spirit-child, one that keeps being reborn and after each birth comes blood and betrayal, the child of ours will refuse to stay till we have made propitious sacrifice and displayed our serious intent to bear the weight of a unique destiny" (494). However, despite all this, Dad is optimistic. He believes that one day:

There will be change [...] and when people least expect it; a great transformation is going to take place in the world. Suffering people will know justice and beauty. A wonderful change is coming from far away and people will realize the great meaning of struggle and hope, there will be peace (478).

For Habermas, the existence of a distinct public sphere mainly rests upon access to full information being guaranteed to all citizens. However, this right is absent in the society being fictionalised in Okri's The Famished Road. For instance, the travails of Jeremiah, the photographer, are reflective of the cat-andmouse relationship between the press/writer and a repressive regime. His ordeals depict the life of many freedom fighters and writers in Africa who are silenced by the government or politicians for attempting to challenge the authority. Many of them have been clandestinely murdered, completely silenced by the government, 
and those who refuse to be silenced live more of their lives in incarceration. Once, the photographer has to disappear for a long time because of minatory attacks on him by the thugs of the Party of the Rich. When his house is attacked, he withdraws into quagmire. He is also dismissed from a relative's house when it comes under surveillance. The cause of his trouble is the taking of the pictures of the riot against the Party of the Rich, at the moment the poisoned milk is being distributed. He takes pictures of the miserable members, especially Black Tyger's landlord who is left reeling in the mire with his torn clothes. He records moments of triumph by the ghetto dwellers and the burnt van of the Party of the Rich. The Party's humiliation gains so much prominence in the papers that thugs seek Jeremiah out for extermination. He is arrested and released after three days, telling the tales of torture and brutality he receives from security agents. For displaying the moments of Rich Party's disgrace in his cabinet for public glare, thugs vandalize it. However, this makes him become a legend, but highly endangered, as he could no more practise his trade without molestation. He now only appears nocturnally, becomes a tramp, leads a vagrant life, and begs for food due to his inability to practise his profession meaningfully again. However, despite being hounded, his courage and uncompromising will to expose the ills of the ruling elite are exemplary and 'legendary'. He, therefore, continues to take pictures of market women fighting with thugs and those of policemen collecting bribes. This is a confirmation of one of the basic tenets of Habermas' public sphere. That is, the public sphere can be animated by opinion-forming associations (voluntary associations, social organizations, churches, sports, clubs, group of concerned citizens, grass-roots movements, trade unions, etc) to counter or refashion the messages of authority.

In this text, Okri transmits, analyses, critiques and even transgresses the socio-historical realities of his nation through engagements with myth and historicity and by probing the images and realities of Nigeria's postcolonial experiences. From these mytho-cultural experiences and sociological inclinations that have a solid ideological subtext arises a successful production of a story that narrates the issue of the failed promise of the public sphere in Nigeria. Although the narrative centres on the Abiku myth and is surrounded by almost unending mysteries, the reader is able to have a full grasp of political issues in Nigeria. If the continuous disorder and chaos in human life, especially in Nigeria, are anything to go by, there is a need to mythologize experiences and break the barriers of conventional realism. This has made Okri's The Famished Road a "distinctive combination of the African, and the European, which reflects the collective modes of discourse underlying postmodern parody" (Ogunsanwo 1995: 48). Okri uses magic, drawn from the African oral tradition, to make a social statement - all is not well with Nigeria's public sphere. 
RULERS AGAINST WRITERS, WRITERS AGAINST RULERS: THE FAILED PROMISE OF THE PUBLIC SPHERE IN...

\subsection{Chimamanda Adichie's Purple Hibiscus: Allegorizing the Failed Promise of the Public SPHERE IN NIGERIA}

Although Purple Hibiscus may be read - on one level - as a family saga, it has political overtones. It captures the socio-political ills of a neo-colonial African country. It is about tyranny (oppression) and people's complicity in their being oppressed; it evokes the Nigerian political landscape powerfully. Through the unhealthy consequences of the filial/domestic conflicts in the story, Adichie makes a call for an all-inclusive public sphere in Nigerian society. In this novel, Adichie pays a special attention to communicative processes in human societies, most especially in the family sphere. The events in the novel are reflective of the wide array of interactions between rationality and power that occur in modern social systems (Habermas 1991). The actions of the paterfamilias of the family depict the factors that constrain the efficiency of the public sphere in modern societies. Habermas opines that public opinion is rational because it takes place "in principle without regard to all pre-existing social and political rank and in accord with universal rules" (Habermas, 1989: 54). However, what is found in the society that is depicted in Adichie's novel is antithetical to free-flow of communication and encouragement of an effective public sphere.

The novel is a political satire that makes a call for change in a nation stunted due to the failed promise of the public sphere. An archetype of an average neo-colonial Nigerian ruler, Papa Eugene, is intolerant and disallows his family members from the public sphere of his household (allegorically the Nigerian neocolony). He is, therefore, depicted as a fanatically religious patriarch, who places too much academic and religious pressure on his children and debars them from interacting with their neighbourhood, their family and the Igbo tradition. Davidson's (1992) comment on the failure of the public sphere in African countries is relevant to the reading of Adichie's Purple Hibiscus as a socio-political allegory:

If the postcolonial nation-state had become a shackle on progress [...] the prime reason could appear in little doubt. The state was not liberating and protective of its citizens, no matter what its propaganda claimed: On the contrary, its gross effect was constricting and exploitative, or else had simply failed to operate in any social sense at all (23).

Therefore, in this article, it is assumed that meaning is not inherent in Adichie's Purple Hibiscus; rather, it is contextual - a function of the situation in which it is articulated. Therefore, this discourse relies on a situated and historical analysis of the specific conditions of the socio-political groups in the story. Thus, Papa Eugene is conceived as a nation's tyrannical ruler; his household is a metonym for the nation, and his family signify the dehumanized citizens of that nation. Papa Nnukwu and Aunt Ifeoma are allegorical representations of the radicals/ 
pro-democracy groups in this nation. In Papa Eugene's 'nation', all the factors that are germane to the success of the public sphere are lacking. This is because the extent of access to the public sphere is not close to universal; the citizens are not free of coercion, and hierarchy is not rejected in the milieu, as each member of the family is not given the right to participate on an equal footing (Rutherford 2000).

From the beginning of the story, Papa displays his masculine dominance in his typical African home setting. It is Palm Sunday, and his son (Jaja) refuses to take communion. On getting home, Papa demands to know why Jaja did not attend the communion. Jaja's reasons are that the substances used as the body of Christ give him bad breath, and the priest touches his mouth nauseatingly. Jaja's refusal to attend the communion infuriates Papa who throws his heavy missal at him. This misses the boy but breaks a glass étagère, a precious possession of Mama. Therefore, the story starts with violence due to the attempt of Papa Eugene to bracket off his wife and children from the family's public sphere. This is first revealed in Jaja's defiance and rebellion: "Things started to fall apart at home when my brother, Jaja, did not go to communion and Papa flung his heavy missal across the room and broke the figurines on the étagère" (4).

Papa Eugene rules his household like a tyrant. This attitude, the narrator juxtaposes with that of the tyrant military Head of State of the nation being fictionalized around the time the story is set. Papa's habitual resort to violence, like an average African despotic ruler, marks the beginning of the breakdown of the family. The family is ruled by the strict authoritarian father, Eugene, who dictates their every move - study schedules, prayer, mass, sleep, church, visitations and the like. He even bans them from spending time with their aged grandfather (his own father) whom he condemns as a heathen. Papa Eugene controls his family through fear and violence, but the violence is never spoken about by the family members who initially keep silent in the face of tyranny. For instance, Kambili and Jaja only communicate with each other through sign language. Papa Eugene's style of 'ruling' his household (his kingdom) is one that offends all known administrative and judicial process, civilian or military. Things are done authoritatively in a manner reminiscent of the Stone Age where bestiality was the order of the day. He adopts a monarchical approach to dealing with his family, talking down to them in a manner that makes them felt unworthy of their being human beings.

In the cosmos of Adichie's Purple Hibiscus, the bourgeois public sphere makes it impossible, even a crime, to offer public opinions that can oppose state power and the powerful interests that can shape bourgeois society. There is a cat-andmouse game between the agents of oppressive forces (the ruler of the day and his cohorts) and resistance forces represented by the tireless press, most especially The Standard. Journalists are always in a privileged position which enables them to mould the opinions of the people by appealing to their sentiments. Unlike other 
professions in which practitioners may die obscure, journalists are exposed to a vista of opportunities on a daily basis, because the community has confidence in them and trusts their judgements. They also have the liberty to address the people and direct their thinking concerning a particular matter. For this reason, journalism becomes a yoke for Ade Coker, the versatile Editor of The Standard. The reason for his ordeals is not difficult to find. The same privilege that he enjoys as a journalist is coveted by the dictator; that is, the capacity to control reason, to reinvent and affect other people's thinking. This gives reason for the prevalent tension between the efficient press (represented by Ade Coker, in this text) and the totalitarian State. The press is reputed to have incredibly withstood the tyranny of Nigerian dictators and has gone above and beyond to scoop news under extremely difficult circumstances at great personal risks. Of the whole group, Ade Coker is portrayed as the arrow-head. He may not have suffered losses greater than any other journalist in the country, but he is more resolute and vows to put an end to the despot's reign by whatever means.

Papa Eugene's religious intolerance symbolizes the ugly side of the Nigerian state. The government of the day is depicted as an intolerant one, most especially in its consistent censoring of the press. According to Father Benedict, Papa "used Standard to speak the truth even though it meant the paper lost advertising" (3). Papa Eugene also asserts, after a coup, that the newspapers in the country "are all afraid. Writing about how corrupt the civilian government was, as if they think the military will not be corrupt. This country is going down, way down" (26). Kambili, the narrator, also adds that "in the following weeks, the newspapers we read during family time sounded different, more subdued" (27). During the military regimes in Nigeria, press freedom was always hampered, mostly extremely. The Nigerian Press, that was known to be voluble, if not irascible, buoyed by a no-holds-barred approach to matters of national interest and with a capacity for advocacy and adversarial haggling against those it considered guilty of malfeasance objective, suddenly lost its salt in the military attempt to subordinate it to the State. This is revealed in the case of Ade Coker, a victim of a government clamp-down, who is eventually killed by a letter bomb. This is a literary intertext of the circumstances surrounding the extra-judicial murder of the popular Editor of Newswatch Magazine, Dele Giwa, in 1986. Thus, in the society being fictionalized in Adichie's novel, the functions of the media have been transformed from facilitating rational discourse and debate within the public sphere into shaping, constructing and limiting public discourse to those themes validated and approved by media corporations and private owners like Papa Eugene.

Also, in the face of military dictatorship, some journalists become hypocritical, constituting themselves as mere appendages of the military. An example of this is 
found in the instances where all the other magazines and newspapers in the nation, except The Standard, refuse to condemn the incessant coups in the country, but instead tagged the recurrence of coups in the nation as "Change of Guard" (25). This confirms Rutherford's assertion that large newspapers devoted to profit have turned the press into an agent of manipulation: "It became the gate through which privileged private interests invaded the public sphere" (2000: 185). The veracity of the claim of Mazrui (2005: 69) that Africa, as a continent, is marked by "conquerability, docility, malleability and fundamental inferiority" is confirmed in the initial docility of the citizens of the society, which is fictionalized in Chimamanda Adichie's Purple Hibiscus.

However, Adichie suggests a way out of the political problem. To have a space in the public sphere of the society, Mama (Beatrice) and her children (Jaja and Kambili) later reject Papa Eugene's despotic and intolerant acts. Therefore, they try to correct the anomalies through protests and defiance by Jaja and Kambili, and later through a 'revolution' or 'bloody coup' by Mama. Also, Adichie does not fail to suggest what the situation ought to be in a true democratic setting. This she does through the use of foil characters like Papa-Nnukwu, Jaja and Kambili, and more significantly, Ifeoma, and her children. Despite the fact that Eugene does everything he could to make his father abandon his faith and embrace the Catholic faith, the old man remains resolute:

Papa-Nnukwu had told the Umunnaow Papa had offered to build him a house, buy him a car, and hire him a driver as long as he converted and threw away the chi in the thatch shrine in his yard [...] Papa Nnukwu laughed and said [...] he would not throw away his chi; he had already told Papa this many times (61).

In spite of his poor conditions of living, Papa-Nnukwu stands his ground. This is a literary testimony to the unyielding anti-dictatorship temper of a few Nigerians who always remain on the side of the masses and refuse appointment offers by tyrannical rulers. Also significant is the tendentious resistance frequently put up by Jaja. The various episodes of his resistance are suggestive of the hidden-cry for Nigerian masses to find a true expression in a society where the promise of the public sphere has remained perennially unattainable.

On a particular occasion, Kambili suffers menstrual cramps on a Sunday morning, and Mama urges her to take pain killers. As a result of this, Kambili takes her breakfast ten minutes before Mass, which, according to Papa Eugene, is a desecration of the Eucharist fast. Papa Eugene is infuriated, without listening to the reason for this desecration. He turns wild:

He unbuckles his belt slowly. It was a heavy belt [...] it landed on Jaja first, across his shoulder. Then Mama raised her hands as it landed on her upper arm [...] I put the bowl down just as the belt landed on my back (102). 
Papa Eugene does not encourage the public sphere to exist in his family; rather, there is an exertion of arbitrary forms of power and domination. Papa's reason for the indiscriminate flogging of his wife with the children is because she watches as the children desecrate the Mass. Papa as a patriarch is well defined - he is cruel, brutal, religiously fanatical, high-handed and oppressive. In another instance, he chops away Jaja's little finger because he misses a question at the Catechism class. Surprisingly, Papa, the looming male figure in the story, is a modern and educated man. However, despite his academic sophistication and business acumen, he is bestial in the way he treats his wife and children. He is hard-nosed, and he subjects his family's pain and paeans to his whims and caprices. He himself gives the reader the impression that his demeanours are conditioned and dictated by religion.

Antagonistic relationships between feminist knowledge/politics and the modernist private/public divide have undoubtedly been a catalyst for women's seclusion, marginalisation and exclusion from the democratic light of the public sphere. One major way this subjection of women has continued and thrived is the traditional belief in the society. In other words, societal customs, culture and ways of life help to facilitate norms that subdue women. Papa's hard-nosed stance is sometimes at the detriment of Mama's health. Once, on their way to visit Father Benedict after church, Mama starts to feel ill at ease because of her pregnancy, and she pleads with her husband to allow her stay back in the car. Papa asks twice, "I asked if you were sure you wanted to stay in the car: "Mama looked up, "I'll come with you; it's really not that bad" (29). She agrees to go with her husband (by coercion) not because she is willing or physically fit enough, but because she does not want to displease her husband. Her initial unwillingness to go on the visit is interpreted by Papa as thwarting God's will by putting her selfish desires first. Papa Eugene so much dominates his family that it is only his voice that is loud. He treats other members of the family as mere appendages. Everything, every action and every belief is ranked and scaled according to his standard. In fact, the politicization of experience (Habermas 1991) has brought the private (the self, the familial, the domestic and the intimate) into a close dialectical relationship with the public. It is, therefore, convenient to agree with Mabura's (2008) reading of Adichie's text as a postcolonial gothic novel. This is because the anti-heroic tendencies of Papa Eugene are similar to the features of a gothic character.

The last brutal act of Eugene against his wife is breaking a table on her belly, thereby terminating her six-week pregnancy: "You know that small table where we keep the family bible, nne? Your father broke it on my belly... My blood finished on that floor even before he took me to St. Agnes. My doctor said there was nothing he could do to save it" (47). One gets the impression that Papa Eugene has gone morally derailed, for his actions cannot be biblically supported. 
Through this, and many other similar events in the story, Chimamanda Adichie is trying to discourage the oppressed from over-condoning injustice and oppression before the dehumanizing acts degenerate. Papa Eugene's anti-democratic posture had initially been taken without any counter-reaction. However, this situation transforms Mama into a violent person as revealed in the event that unfolds later. Before her transition into a radical feminist, Mama is depicted as a quintessential womanist who does not import Western feminist ideologies into the African worldview. Rather, she establishes a 'safe' point that is favourable to the worldview. She also recognizes the nature of her society as being ancient, and that practices and traditions that have existed for years might not be easily changed. With these ideas, she rejects the proposal by her sister-in-law, Ifeoma, on the need to call her marriage off considering the brutalities she has experienced.

Therefore, propelled by her natural pacifist ideology, Mama initially endures her marriage, hoping things will change for the better. For instance, rather than become furious as a result of the unfair treatment meted on her by her husband, Mama always remains calm. In a particular instance, when Papa beats her and her children, Mama takes the belt he uses to flog them from him and lays it on the table. However, human patience and resistance to injustice is definite and limited. Patience, alongside the mechanism for its operation and manifestation, is elastic. It detaches upon further stretching; that is, one tends to exhaust one's patience when evolving circumstances are ridiculous, hence unbearable. As a result of this, Papa Eugene's death, through poisoning, is Mama's way of asserting herself and her will. Papa Eugene's tragic end confirms the assertion that oppression will always meet with equal resistance, no matter the place and people, and that good triumphs over evil ultimately, no matter how long evil lasts. The narrator recalls Mama's ingenious way of exterminating the source of her (and her children's) woes:

They have found the poison in your father's body. She sounded as though the poison in Papa's body was something we all had known about, something we had put in there to be found, the way it was done in the books I read where white people hid Easter eggs for their children to find (290).

Mama's system of eradicating Papa Eugene, because of his overbearing attitude, is in consonance with the principle of Radical Feminism; that is the adoption of violence in putting an end to masculine dominance, hence enhancing the liberation of women from the alleged bondage in which men have put them. Through the dissenting relation of Mama to the dominant patriarchal tradition of Africa, Chimamanda Adichie is insinuating that the dimension the feminist campaign is taking currently is bitter, and arms alternative is impending in the nearest future. 
This insinuation has a trait in the latter-life radical temper of Mama. This is also revealed in Mama's confession to killing her husband: "I started putting the poison in his tea before I came to Nsukka. Sisi got it for me; her uncle is a powerful witch doctor" (290). This is a reflection of the radical dimension to feminist ideology in most African countries. Mama now believes, like other radical feminists, that violence is the most effective strategy for achieving her freedom. However, one wonders why the woman, who had been submissive to a fault, suddenly turns out to be the murderer of her husband. It is also discovered that the violent dimension to the whole situation is to make the statement that there is aggression hidden in every patient woman (the representative of the masses) and that circumstances may impel her (them) to it to safeguard herself (themselves). It also means that silence should not be taken or interpreted to mean foolishness, laziness, complacency or stupidity. Thus, Mama's later radical temper is in line with Habermas' theory which seeks to break the stranglehold of the totally administered society by exploring the emancipatory potential of communicative rationality. The public (represented by Mama) challenges the absolute sovereign rule by force, will and secrecy.

African women are asserting themselves in different ways and techniques; it is just that hopeless situations, at times, need radical solutions. The central character, Kambili, the representative of the author's ideology and beliefs, revolts against the established norms in a society where the promises of the public sphere have consistently failed. Therefore, Adichie envisions a nation where the disempowered womenfolk (the masses) will transgress heterosexual codes in order to free themselves from the shackles of patriarchal suppression. This is an element of resistance against the processes of objectification and heterosexual oppression. Thus, Mama, Kambili and the male-feminist (Jaja) oppose compulsory heterosexuality and gender constrictions in order to liberate their true selves and desires. In fact, the enduring brilliance of Adichie's Purple Hibiscus is its ability to oppose hegemony in an effort to counterbalance the distribution of power and challenge the authoritative power that disempowers the African woman (the marginal subject). Through this effort, Adichie re-empowers the womenfolk (the masses) by giving them a space from which they generate alternative interpretative modes and, in turn, speak out and become an agent of their own history. Towards the end of the story, the trio (Mama, Jaja and Kambili) formerly positioned in the peripheries, now move in a series of resisting movements - translocation and masquerading. Consequently, they are able to protect themselves from being totally decoded. This ultimate resistance serves as a buffer to help in preventing Papa Eugene's continuing acts of appropriation and egocentric manipulation of the family's (nation's) Public Sphere. 


\section{CONCLUSION}

Achebe, Okri and Adichie have enriched and enlarged the discourse of the failed promise of the public sphere in Nigerian socio-political set-up through the ideas promoted in their individual works. Despite all odds against their lives and arts, Nigerian writers continue to disentangle their dilemma both as writers and public intellectuals. They refuse to be caged, and they constantly intervene in the public sphere of their nation. In the novels treated in this paper, there is the suspicion of the public sphere, which is depicted by the absence of a public concern with the sphere. This is an imaginative mimetic representation of the social urgency of fragmentation, state oppression, censorship of Nigerian writers and the masses and increasing national exploitation. The political concerns of Nigerian writers, most especially the desire to take on the power of representation of neocolonial disillusionment in their country and serve as the conscience of the nation, are vividly exposed. Nigerian rulers have refused to allow the public sphere to be practicable and accommodate every member of the society. In fact, the actions, inactions, histrionics and dialogues of the characters in the selected novels reveal that the little political freedom granted the Nigerian masses during the colonial period has disappeared due to the unbridled power of the rulers and their fierce pursuit of self-interest.

The idea that is emphasised in the novels is that, instead of engaging in free 'interchange' of views, Nigerian neo-colonial rulers, fictionally represented by the President for Life of Kangan (Nigeria) in Anthills of the Savannah, the fanatically religious paterfamilias (Papa Eugene) in Purple Hibiscus and the violent politicians in The Famished Road, repress, judicially murder and jail the governed for daring to express views which are different from the rulers'. This is symptomatic of the breakdown of the public sphere into violence in the milieus of the texts. Therefore, in this period of terror, feeble democracy and dictatorship in the country, the public sphere is sacrificed to the urgency of political action. This confrontation makes Ikem (in Anthills of the Savannab), Kambili and Jaja (in Purple Hibiscus) and the hopeless masses (in The Famished Road) realize that there is a fundamental contradiction between the utopian space of the public sphere and a tyrannical system of governance in Nigeria that remains largely unchanged since independence.

Achebe, Okri and Adichie present the failed promise of the public sphere as an important element in Nigerian political society. Therefore, this paper argues that the novelists, in their respective texts, represent the problem of the potential expansion of the utopian state (the public sphere) to include the political and social concerns of Nigerians; that is, the desire of Nigerian masses to take on the power of representation and to speak for themselves. It is also argued that their 
novels reveal Nigerian rulers' refusal to become more inclusive. Ikem (in Anthills of the Savannah) Black Tyger and Photographer (in The Famished Road) and Jaja, Kambili and Mama (in Purple Hibiscus) who think their voices should be heard on public issues, are expelled from the public sphere.

It has also been established that, beyond exhibiting topicality and stylistic innovations, postcolonial Nigerian fiction offers a sustained exploration of the issue of the failed promise of the public sphere, a much-needed theme in current Nigerian literary discourse. It is revealed that, despite all odds against postcolonial Nigerian fiction writers, there is no sign that an interest in literature of commitment is waning in the country. The reading public of Nigerian fiction has been given a clearer picture of the conditions of the nation's masses than the one offered on the television, radio and the print medium. What the three selected novelists have in common, thematically, is a scathing exposure of post-independence disillusionment, a result of the failure of the new governing classes to fulfil the emancipatory promises of independence. Thus, what stands foregrounded in the novels is the disillusionment of the masses, that is, the disgust felt with the mess that their elected representatives and the military rulers have made of their country. What is highlighted and critically interrogated in the texts is the attempt of the rulers to erode the legitimacy of a defensible core of rights (public sphere). There is, therefore, a sense in which we can say that postcolonial Nigerian fiction offers imaginative case studies of allegations of violated human rights in the nation. Questions of human rights' abuse and the failed promise of the public sphere dominate both the trajectory of the plots and the philosophical quandaries at issues in the three selected texts. The formal structures of the novels also revolve around dissonance between rulers and the ruled, as a result of the conspicuous failure of the public sphere. The texts give imaginative representations of the many theoretical reservations about the public sphere, offer a vision of human vulnerability and dependency that presents a much-needed corrective to the excessively inflated present-day aspirations for human rights.

The survival of the philosophy of harmony and integration among the diverse people of Nigeria, that is, the concept and significance of the collective will, is being threatened in the cosmos of each of the novels. Due to the refusal of the rulers to allow the masses to be active participants in the nation's public sphere, the expected collective will is jettisoned in favour of the European cosmic will. Collective will is a force that operates in a communalistic society like Nigeria, where the emphasis for group survival overrides that of the individual. The primacy of place is supposed to be given to the group rather than the individual, because it is understood that the part exists within the whole (Sofola, 1988). Therefore, Sam, the Head of State of Kangan (in Achebe's Anthills of the Savannah) the corrupt 
politicians and their cohorts (in Ben Okri's The Famished Road) and Papa Eugene, the tyrannical, puritan and fanatical paterfamilias (in Chimamanda Adichie's Purple Hibiscus) advertently forget that, in Africa, the power and strength of the individual exist in the strength of the collective will of the group (Nkrumah's Conscienticism, 1964). Each of the fictional despots falls from grace to grass because of his hubris; that is, appropriation of the power of the collective will to themselves.

It can, therefore, be inferred that the novelists, through their works, seem to be suggesting that all-involved public sphere and freedom of the press and creative writers are the cornerstone of democracy. Nigerian writers have a right to serve as the conscience of their society. Therefore, Nigerian writers should be able to enjoy the hard-won freedom of imaginatively reflecting and refracting the foibles of their rulers and the ruled. Neo-colonial Nigerian rulers should see the writers as partners in progress, rather than seeing them as illegitimate interlocutors in the nation's public sphere.

Given all that has been discussed about the problem of the failed promise of the public sphere in Nigeria, as narrated in the selected prose texts, it is suggested that there should be a harmonious blend of all the segments of the citizens of the nation (poor or rich, young or old, female or male, disabled or non-disabled, employee or employer, ruler or the ruled, literate or illiterate, and the like) to enable each citizen fulfil his/her destiny and achieve the inalienable right of selfrealization and actualization without the destruction of the whole. It is the total rejection of this philosophy that leads the rulers in the texts to have tragic ends. They use the power vested in them to destroy other lives and are, therefore, evil agents who must be punished and expunged. Therefore, one didactic message which is a motif in postcolonial Nigerian fiction is that legal and obedient citizens of the country must be allowed to take their rightful place in the order of the universe and the political set-up of the nation, and they must seek to maintain cosmic equilibrium in the nation. This viewpoint conscientizes the masses of the societies portrayed in the selected novels to engage in real and latent revolts. They are ready to drive basic issues home and effect a change. This temper may offer an antidote for leading our groping nation from the woods of confusion, despotism, totalitarianism and anarchy.

\section{REFERENCES}

Abdullahi, D. 2008. "The State vs The Writer: Kano Writers on War". The Nation, Wednesday, August 6, 26-27.

Achebe, C. 1984. The Trouble with Nigeria. London: Heinemann. 
RULERS AGAINST WRITERS, WRITERS AGAINST RULERS: THE FAILED PROMISE OF THE PUBLIC SPHERE IN...

Achebe, C. 1987. Anthills of the Savannah. London: Heinemann.

Adichie, C. 2003. Purple Hibiscus. Lagos: Farafina.

Ajibade, K. 2003. Jailed for Life: A Reporter's Prison Notes. Ibadan: Heinemann.

Cooper, B. 1998. Magical Realism in West African Fiction: Seeing with a Third Eye. New York: Routledge.

Davidson, B. 1992. The Black Man's Burden: Africa and the Course of the Nation State. New York: Times Books.

Elliot, R. 1972. The Power of Satire. Magic, Ritual, Art. New Jersey: Princeton.

Fanon, F. 1968. The Wretched of the Earth. New York: Grove Press. Trans. Constance Farrington.

Fraser, N. 1992. "Rethinking the Public Sphere: A Contribution to the Critique of Actually Existing Democracy". Habermas and the Public Sphere. Ed. C. Calhoun. Cambridge, MA: MIT Press. 1-32.

Freedom House. 2008. www.freedomhouse.org//accessed 23 July.

Frye, N. 1945. "The Nature of Satire". University of Toronto Quarterly. XIV: 79-80.

Glover, B. 2004. The Public Sphere and Formal Nostalgia, 1709-1785. Ph.D Dissertation, University of Virginia.

Habermas, J. 1987. The Philosophical Discourse of Modernity. Cambridge: MIT Press.

Habermas, J. 1991. The Structural Transformation of the Public Sphere: An Inquiry into a Category of Bourgeois Society. Cambridge, MA: MIT Press. Trans., Thomas Burger and Frederick Lawrence.

Habermas, J. 1996. "Popular Sovereignty as Procedure". Cambridge: MIT Press, Between Facts and Norms. Trans., Williams Rehg. 463-90.

JanMohamed, A. 1983. Manichean Aesthetics. Amherst: University of Massachusetts Press.

Kehinde, A. 2005. "Rethinking African Fiction in the Era of Globalization: A Contest of Text and Context." Journal of the Nigeria English Studies Association, Volume 11(1): 87-100.

Liman, A. 1999. "Postcolonial Discourse: The Case of Ben Okri's Famished Road. Currents in African Literature and the English Language, Volume 1(1): 63-79.

Mabura, L. 2008. "Breaking Gods: An African Postcolonial Gothic Reading of Chimamanda Ngozi Adichie's Purple Hibiscus and Half a Yellow Sun". Research in African Literatures 39 (1): 203-22.

Mazrui, A. 2005. "The Re-invention of Africa: Edward Said, Y.Y. Mudimbe and Beyond". Research in African Literatures 36 (3): 68-82. 
Ngara, E. 1990. "Achebe as Artist: The Place and Significance of Anthills of the Savannah." Kunapipi 12 (2): 113-29.

Nkrumah, K. 1964. Conscienticism. London: Heinemann.

Ogunsanwo, O. 1995. "Intertextuality and Post-Colonial Literature in Ben Okri's The Famished Road". Research in African Literatures 26(1): 40-52.

Ojinma, U. 1991. Chinua Achebe: New Perspectives. Ibadan: Spectrum.

Okri, B. 1991. The Famished Road. London: Jonathan Cape.

Osundare, N. 2007. The Writer as a Righter. Ibadan: Hope Publications.

Osundare, N. 2008. "The State vs The Writer: Kano Writers on War". The Nation, Wednesday, August 6, 26-27.

Rabo, A. 2008. "The State vs The Writer: Kano Writers on War". The Nation, Wednesday, August 6, 26-27.

Ritzer, G. 2000. Sociological Theory. New York: The McGraw-Hill.

Rutherford, P. 2000. Endless Propaganda: The Advertising of Public Goods. Toronto: University of Toronto Press.

Sofola, Z. 1988. "African Society and the Concept of Freedom". Okike 27/28: 74-87.

Szeman, I. 1952. On National Cultures: Literary Politics in Canada, The Caribbean and Nigeria, 1952-1970. Doctoral Thesis, Duke University.

Williams, A. 1996. "Literature in the Time of Tyranny: African Writers and the Crisis of Governance". Third World Quarterly 17(2): 349-62.

Young, C. 2004. "The End of Post-colonial State in Africa? Reflection on Changing African Political Dynamics". African Affairs 103: 23-49. 